\title{
TOC LOGICAL BRANCH AS A TOOL IN TEACHING POLISH AS A FOREIGN/SECOND/HERITAGE LANGUAGE TO CHILDREN
}

Keywords: TOC tools, a logical branch, teaching Polish as a foreign/second/heritage language, Polish language as a foreign/second/heritage language for children

\begin{abstract}
This article is devoted to the presentation of the author's solutions in adapting one of the TOC thought tools to teaching Polish as a foreign/second/heritage language, specifically to children. TOC tools were primarily developed for the business sector as a tool for diagnosing areas which should be modified or improved. Applied in the sphere of education, the tools turned out to be universal methods of supporting students' cognitive processes. In the existing research on the possible applications of the TOC methodology, no attention was paid to its use in the field of Polish as a non-native language didactics, and the TOC tools seem to be a useful solution in teaching foreign languages to children. The article presents proposals for the use of the so-called logical branch to explain grammar rules in teaching Polish to children. The discussed tool may perform this function well as it conforms to the standards of the methodology appropriate in children's language education: It is attractive as a graphic tool, it shows the structure of the Polish language system in a transparent and orderly manner, it has mnemonic values, it can be also used for games, as well as allowing for flexibility (differentiation) of the didactic process.
\end{abstract}

\section{INTRODUCTION AND BACKROUND}

Today, teaching Polish as a foreign and second language to children is one of the major challenges of Polish as a foreign language pedagogy due to the increasing number of migrants and refugees in Europe. It should be noted, however, that new educational needs have a wider context, since they concern the entire Polish educational system, which must change towards teaching in multicultural conditions. As Szybura notes, "education of foreigners and re-emigrants is a chal-

*1umina@kul.pl, Katolicki Uniwersytet Lubelski Jana Pawła II, Wydział Nauk Humanistycznych, Instytut Filologii Polskiej, Katedra Języka Polskiego, Al. Racławickie 14, 20-950 Lublin. 
lenge for an increasing number of schools in Poland, which, thanks to the presence of students coming from all over the world, become multicultural schools" (Szybura 2016, p. 99). One of the forms of education conducive to multicultural education, and at the same time a distinctive trend in foreign language teaching today, is combining language education with other skills, so-called integrated language and subject teaching, which in its most advanced form is bilingual teaching (Sobczyńska 2016). Such an educational strategy obviously requires searching for new, or adapting already used, methodological tools to the chosen educational model, although - as methodologists emphasize - the approach to foreign language teaching is generally characterized by broadly understood eclecticism - an obvious procedure not only in the case of the integrated teaching (Rokita-Jaśkow 2015).

In the case of children's education, the psychological and developmental conditions that are crucial in planning the educational process are especially important. They include the following factors: 1) low attention capacity and the advantage of involuntary memory over any other, which translates into the need to frequently change the type of exercises in order to increase their attractiveness; 2) the need to build internal motivation of students through attractive and emotionally engaging tasks; 3 ) the advantage of mechanical memory over the logical, which means that in order for children to be able to remember texts, phrases, new words, etc., they have to be repeated many times, in different forms and in different contexts (Schaffer 2006). The potential for effective consideration of these factors has also been noticed in the Theory of Constraints (TOC) thought tools, which in the presented article are discussed in the context of teaching Polish as a foreign/second/heritage language.

The TOC tools were developed by the Israeli physicist Eliyahu M. Goldratt, who, in search of methods of cooperation with business, developed a program called the Theory of Constraints - the theory of limitations ${ }^{1}$. The essence of this program was the application of hard scientific methods to solve economic and managerial problems in companies. On the initiative of Goldratt, the institution TOC for Education was established, and has been operating since 1995: today it has branches all over the world². According to Kamińska, "TOC program supports children and adolescents in the process of acquiring the ability to communicate clearly with others, to identify and express their own needs, to strive for a goal and predict the consequences of events related to decisions in every aspect of life [...]. Its task is to prepare children to make informed decisions and take responsibility for them, and persistently strive to achieve their goals, as well as develop respect and empathy. It is so universal that it can be used both in kindergarten and at school (including work with children and young people with disabilities)" (Kaminska 2012, p. 14). For this reason, in some European countries, TOC tools have been

\footnotetext{
${ }^{1}$ The information on TOC tools is based on Kamińska 2012.

${ }^{2}$ http://w.tocforeducation.com/home.html [19.04.2019].
} 
adapted to, among others, educational activities in the process of looking for ways to work with children which would best support the acquisition of the so-called key competences and basic skills. These have been defined in European Commission documents ${ }^{3}$, and described as the most important competences for the students growing up in the contemporary, globalized world. Proponents of the TOC application in education claim that their use is appropriate for students of all ages.

The TOC tools are distinguished by three elements known as a logical branch, a tree of ambition and a cloud. The use of the branch helps to identify the consequences of decisions, actions and ideas that lead to negative outcomes, and convert them to positive outcomes. A tree of ambition enables the creation of an effective plan by overcoming obstacles that block the attainment of a goal, whereas a cloud is a tool that can be used in teaching how to resolve internal and external conflicts without compromising important needs ${ }^{4}$. It is emphasized that all the tools enable worthwhile educational processes whether in the classroom, in a textbook, or in the boardroom.

The TOC tools have been also applied by Polish educators and the TOC program for education has been developing for many years ${ }^{5}$. One of the latest proposals regarding the use of TOC tools in education is a study on their application in supporting educational processes in Polish schools abroad ${ }^{6}$. This publication, known as ORPEG (2019), has been prepared and released by the Center for the Development of Polish Education Abroad and is the first study that recommends the use of TOC tools in Polish diaspora education. It is motivated above all by the need to improve critical thinking, especially in the context of the intensive increase in information and communication technologies. As we read in the document, "the development of modern information and communication technologies, beyond undeniable benefits, has brought many threats. Information that "seeks out and floods" students is often incorrectly evaluated and processed. Analysis and evaluation of available information for verification and selection have become more important than ever before. A Polish school abroad should develop the student's key competences, including the ability to be a consumer of information. Contemporary reality throws educational institutions outside the borders of Poland a new challenge - to teach new types of reasoning skills on the verbal material, and, thus, essentially the skills of critical thinking"'. As one of the methods that can be used at school (for every subject and educational level) to develop critical thinking, ORPEG recommends the use of TOC tools.

\footnotetext{
${ }^{3}$ See: https://ec.europa.eu/education/policies/school/key-competences-and-basic-skills_en [19.04.2019].

${ }^{4} \mathrm{http}: / /$ w.tocforeducation.com/home.html [19.04.2019].

${ }^{5}$ See the website: http://www.toc.edu.pl/ [19.04.2019].

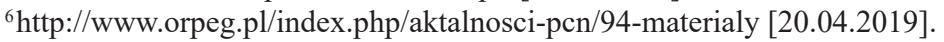

${ }^{7} \mathrm{http}: / /$ www.orpeg.pl/index.php/aktalnosci-pen/94-materialy [20.04.2019].
} 


\section{POLISH LANGUAGE AS A FOREIGN/SECOND/HERITAGE LANGUAGE FOR CHILDREN}

While discussing any issues regarding the teaching of Polish language to children in a context other than teaching it as a mother tongue, reference should be made to the latest theoretical and methodological findings in this area. In contemporary Polish language pedagogy, three different approaches to teaching Polish language and culture, the differentiation of which results from a broadly understood educational context, are distinguished. These are teaching Polish 1) as a foreign language, 2) as a second language and 3) as a heritage language.

Teaching Polish as a foreign language deals with the teaching of Polish language and culture to foreigners - in this case, the recipients of education can be children, teenagers and adults. The term teaching Polish as a second language is the latest term and it refers "to the teaching of Polish language in Poland to children of immigrants and political refugees and children belonging to national minorities who use a language other than Polish in a family environment" (Miodunka 2010, p. 240). The establishment of such a term (and such a methodological approach) is a response to the socio-cultural and political realities of recent years, distinguished by massive migrations on the European continent. The term was originally intended to include Polish language education in the Polish diaspora, however, the diaspora did not accept the term second language in relation to the Polish language, which they still treat as a mother tongue. For this reason, the notion of Polish as a heritage language (in other words: posterity, succession language) was introduced to Polish research by E. Lipińska and A. Seretny (2012). According to the researchers, the term heritage language is the most appropriate for naming the Polish language used by children growing up in Polish communities abroad. This is because of the fact that it is "acquired first, but its users rarely achieve full competence", besides, the adjective heritage "combines family values and wealth of national heritage" well (Lipińska, Seretny 2012, p. 21). As Miodunka points out, "this skilful combination of family values with the (entire) richness of the national heritage is the greatest value of the term heritage language, a value that second language certainly lacks. Emphasizing this, we want to draw attention to the fact that only a good knowledge of the written variant of the heritage language gives access to the entire national heritage, preserved in the literature created in the language of the Polish nation" (Miodunka 2016, p. 293).

The terminological distinctions mentioned above make us aware of the wide range of didactic contexts for teaching Polish (besides as a native language) at the present time, and how numerous the didactic needs in this area are. All the indicated types of teaching require a separate methodological approach and diversified educational strategies, but in each of them one can use the same (or similar) tools 
that are appropriate in didactics directed at children. Moreover, this diversity of teaching contexts should inspire the search for and implementation of new tools or solutions, especially textbooks and educational materials for children which (compared to those for adult students) are very few, and in every type of Polish language teaching (as a foreign, second, or heritage language) there are growing needs in this area. In addition to focusing on the preparation of standard teaching materials, it is also worth reaching for innovative ideas in the education of children and youth, and verifying their usefulness.

\section{THE LOGICAL BRANCH IN CHILDREN'S EDUCATION AND IN TEACHING THE POLISH LANGUAGE}

As the methodologists who deal with using the TOC tools in education claim, "the logical branch supports the child's learning process, including the ability to think logically, by creating and understanding cause-and-effect relationships [...] and their consequences. Thanks to this, the child better understands the scientific and mathematical principles and is able to creatively analyze the content of stories and literary works" (Kamińska 2012, p. 15). One of the benefits of using a logical branch in the education process that this tool "enables the development of the linguistic and communication skills of the child, including dialogue language, sentence expression, and also fosters the enrichment of the vocabulary" (Kamińska 2012, p. 16). It can, therefore, be concluded that the logical branch is a useful tool to strengthen the child's natural cognitive and educational predispositions. As emphasized by researchers dealing with psycholinguistic foundations of foreign language didactics, human cognitive and communication processes remain closely interdependent, and, therefore, the acquisition of foreign languages as a cognitive process can only be implemented on the grounds, and in the form, of language communication (Dakowska 2001, p. 10). At the same time, "teaching strategies are determined by our knowledge of human cognitive functioning in the language communication processes in the sense that in order to support or enable them, we must closely adapt our activities to the subsystems, processes and cognitive structures functioning in the mind, as well as the regularity of memory" (Dakowska 2001, p. 10).

The use of a logical branch in the previously applied work models at the level of early school education is based on determining the sequence of events and discovering cause-and-effect relationships between them. In this process, it is important for the child to see the differences and links between the individual elements of the branch, and also to be able to argue their opinions and observations. Depending on the level of cognitive development and the level of argumentative 
capabilities in working with a logical branch, a simple or complex scheme can be used. The former (Figure 1) allows for building (communicating) simple structures in which the child is able to express a causal link that they understand. However, the latter (Figure 2) reflects more complex thought processes, at the same time enabling verbalization of extensive messages (extensive language structures) in which there is a place for components related to justification, argumentation or explanation.

Figure 1. The logical branch - the simple diagram.

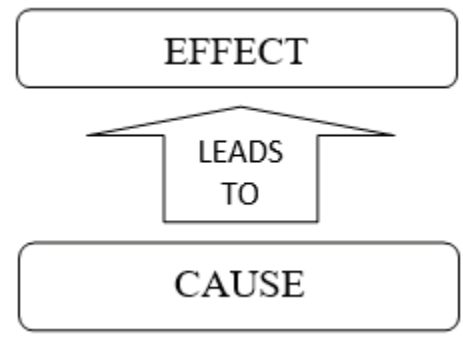

Figure 2. The logical branch - the complex diagram

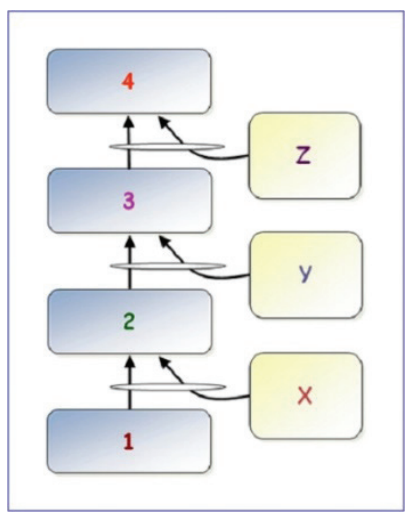

Source: http://www.toc.edu.pl/co-to-jest-toc/narzedzia-toc/ [19.04.2019]

Visualization of thought processes by means of a logical branch is very important to the question of memorization in the learning process, which plays a special role in learning foreign languages. In today's foreign language methodology, more and more space is devoted to mnemonics and its use in the teaching process. Karbowniczek, among others, draws attention to this issue: "From didactic practice, we know how difficult it is for teachers to introduce linguistic material to their pupils. The basic condition for successful implementation of this process is proper memorizing of the information provided to them. Psychological research 
shows that the effects of memorizing can be increased with appropriate guidance in teaching" (Karbowniczek 2012, p. 90). Bilbrough, in his book devoted to the relationship between the processes of memorization and the acquisition of foreign languages, states categorically that there is no learning without remembering (Bilbrough 2011).

Working with a logical branch also introduces a component of movement to the didactic process - elements presenting the subsequent stages of the narrative are usually either laid on the floor (younger children) or written on a blackboard (older children). The use of a logical branch therefore responds to the natural need for movement in students. It is worth remembering that both in early childhood and later (between ages 9 and 12), pupils are much more willing to acquire new content - and better at it - if it is accompanied with movement (Przewęda 1981). Also, as Jagodzińska claims: “(...) research has shown, children remember more pictures when they are arranged according to some principle than when they are only asked to remember" (Jagodzińska 2003, p. 21), and as Szewczuk states: "An individual remembers only what is involved in an activity" (Szewczuk 2000, p. 189).

The diagrams presented above and their importance in children's education make the logical branch a promising tool in teaching the Polish language to children in all possible contexts: as a foreign language, a second language and a heritage one. In the above-mentioned ORPEG document, attention is drawn to the use of TOC in the education of Polish diaspora pupils from the perspective of key competences relevant to young generations in the era of widespread technologicalization 9 . In this paper, I want to propose the use of a logical branch to teach Polish grammar and to present solutions in which the logical branch scheme is used as a tool for interpreting rules of grammar. The orderly pattern of the branch favours the simplicity of the interpretation; it visualizes the principle, which in a descriptive manner would probably be much harder to remember and master; and, it enables the automation of language rules, i.e. their preservation. As pointed out by Jędryka: "Teaching the syntax of Polish as a foreign language is not the easiest task. Mastering it requires many repetitions of syntactic schemes and the use of acquired knowledge in the field of subjective and verbal inflection. It also requires the development of certain reflexes so that they appear naturally - automatically [...]" (Jędryka 2012, p. 127).

In the use of the logical branch for the purposes of Polish language teaching, its construction almost immediately directs the instruction towards the predication syntax - the branch scheme seems to be of great help in introducing and practi-

\footnotetext{
${ }^{8}$ See also: Kotorowicz-Jasińska, Śpiewak (2016).

${ }^{9}$ See: "Teachers of Polish language and Polish culture outside of Poland can significantly contribute to the explosion of popularity of critical thinking education, whose goals are particularly adequate to the needs and social expectations of the $21^{\text {st }}$ century" (ORPEG 2019).
} 
sing structures of subordinate clauses. However, a slightly more creative view of this model allows it to be applied to other types of grammatical structures of the Polish language, including both syntactic and inflectional ones. In the diagrams below, there are a few proposals for such applications. These are ideas for a creative approach to the logical branch scheme - creative in the sense that they are an attempt to display a chosen grammatical structure as transparently as possible. In each case, the most important principle is that the logical branch illustrates the model framework of a given structure so that it would help the student produce the correct text in Polish.

1. Syntax of nominal predicate: nominative case versus instrumental case

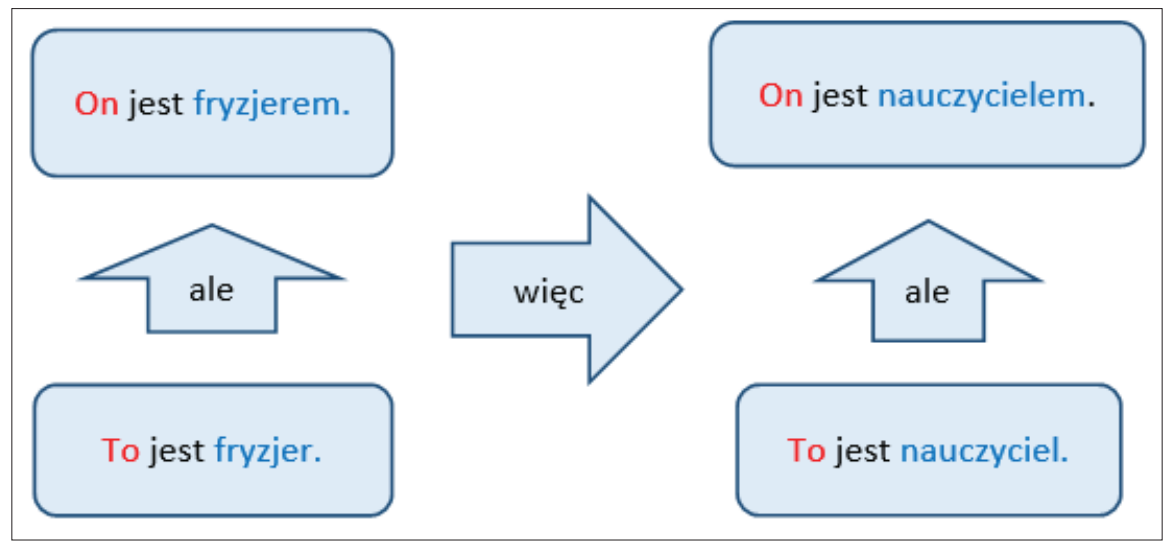

2. Negative structures: accusative case versus genitive case

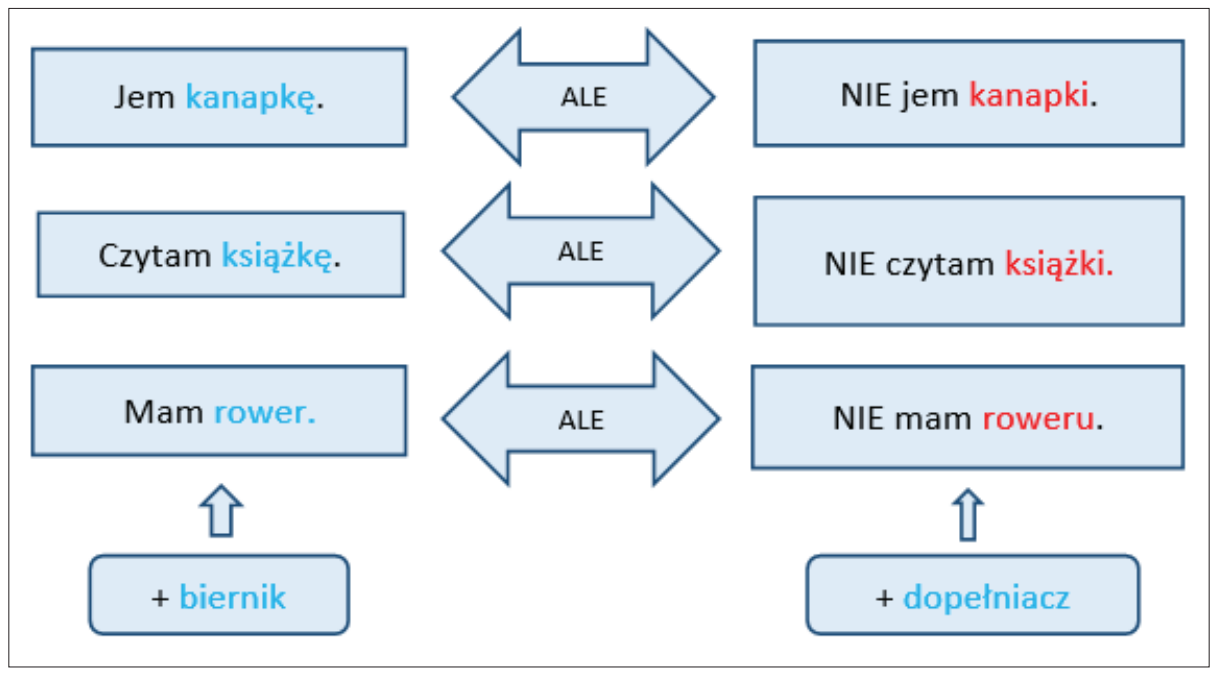


3. Syntax of cardinal numbers

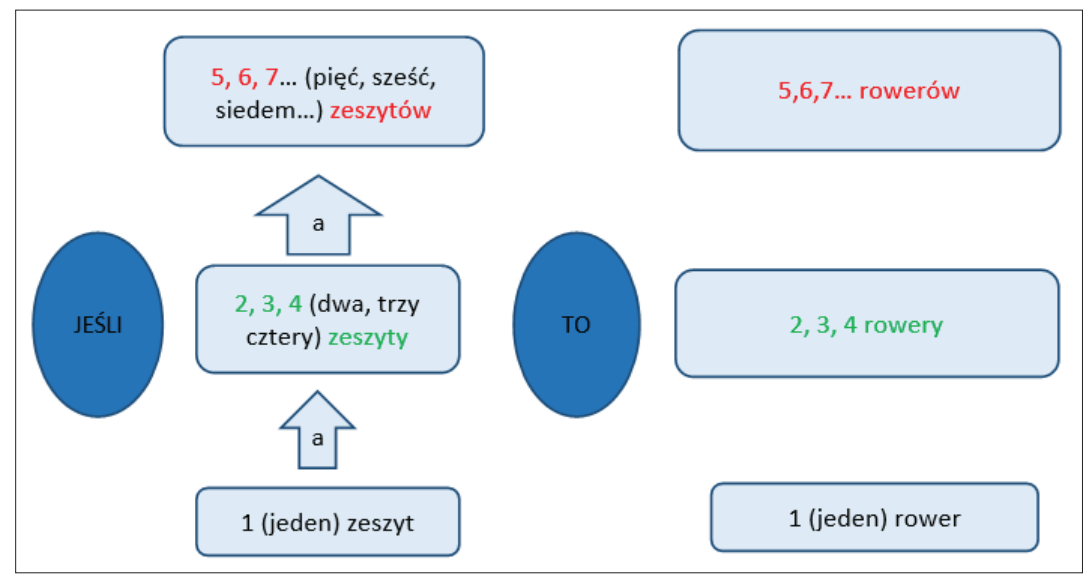

4. Instrumental case in construction "something with something else"

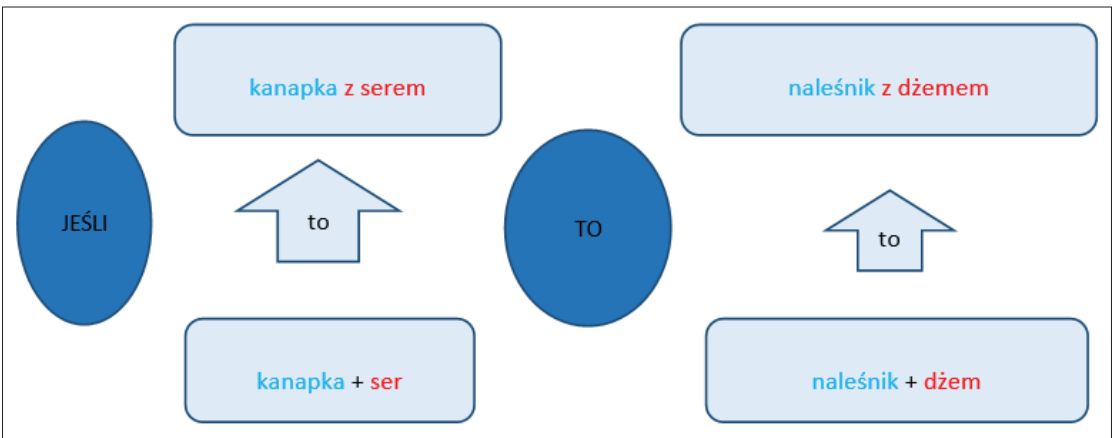

\section{Grammatical gender of adjectives}

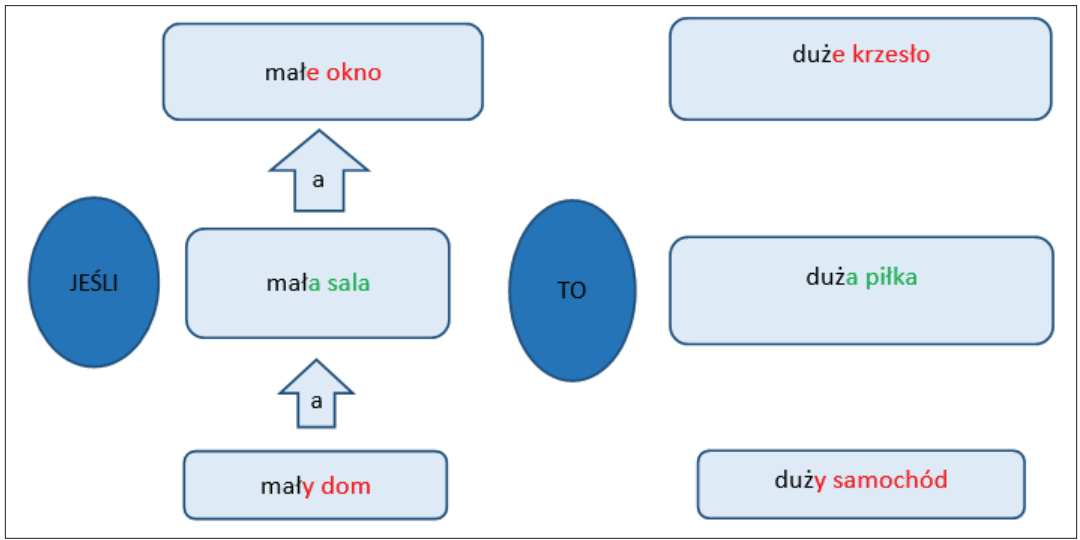


6. Possessive pronouns versus nouns

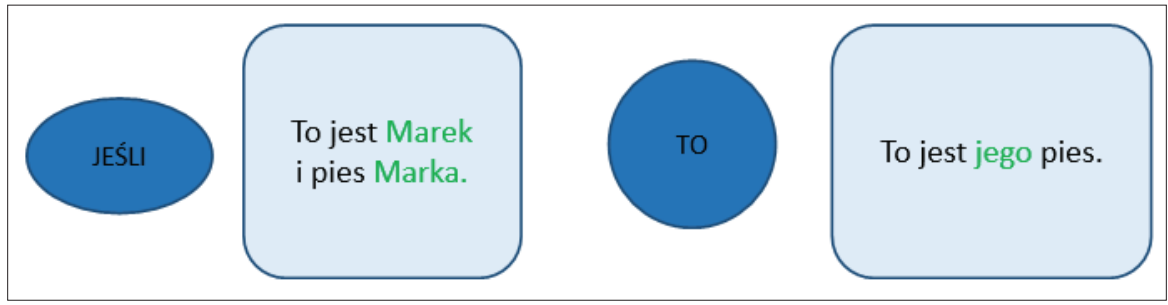

\section{CONCLUSIONS}

The application of the discussed TOC tool in teaching Polish grammar - in the context of children's language education - is an innovative proposal as a didactic solution, but not innovative in the sense of the contemporary understanding of foreign language didactics. The use of a logical branch in teaching children is the implementation of an interdisciplinary approach to the development of Polish as o foreign/second/heritage language theory and practice, and interdisciplinarity should be already a rather obvious approach for researchers dealing with teaching and learning foreign languages. As Dakowska emphasizes, "contrary to the earlier stages of the development of foreign language teaching theory, currently related fields are no longer a source of theory or definition of the main components of the learning and teaching process. [...] they are important partners in linguistic didactics due to the fact that they deal with key aspects of the cognitive and social functioning of people, which cannot be clearly separated from the processes of linguistic communication" (Dakowska 2001, p. 9) ${ }^{10}$.

Conclusions that crown the use of the logical branch as a model supporting teaching of selected grammatical problems of the Polish language, which have been indicated in the article, can be formulated as follows:

1. The logical branch works well as a model of the interpretation of grammar rules in the teaching of children, because:

- it is attractive as a graphic tool,

- it shows language structures in a transparent and structured way,

- its use incorporates the movement component into the teaching (movement promotes the consolidation of knowledge),

- it has mnemonic value (it facilitates memorization),

${ }^{10}$ Compare also with Pffeifer's statement: "The interdisciplinary orientation of foreign language teaching is its advantage, not weakness" (Pffeifer 2001, p. 56). 
- it allows for flexibility in the didactic process: depending on the purpose of the lesson and the linguistic proficiency of pupils, one can concentrate the work with the tool on the more desirable efficiency: either strictly linguistic or linguistic-logical.

2. The logical branch can be used not only as an interpretation of grammatical rules, but also as a tool for their preservation. Work with a logical branch can be modified and made into a form of language game or play aimed at implementing specific components of the language system. And, as it is known, "the task of games implementing a foreign language system is to develop the ability to recognize and construct statements correct in terms of form" (Karbowniczek 2012, p. 71).

3. It may be also stated that working with a logical branch creates a great chance to implement the principle of success in teaching Polish as a foreign, second or heritage language in groups of children. This is a general teaching principle, which emphasizes that all students should feel successful in the learning process - even students with lower language skills (Pfeiffer 2001, p. 58-59).

\section{REFERENCES}

Bilbrough N., 2011, Memory Activities for Language Learning, Cambridge.

Brzeziński J., 1987, Nauczanie języków obcych dzieci, Warszawa.

Jagodzińska M., 2003, Rozwój pamięci dziecka w dzieciństwie, Gdańsk.

Jędryka B., 2012, Język polski w polonijnej szkole. Na przykładzie badań przeprowadzonych w Clark - New Jersey, USA, Warszawa.

Kamińska D., 2012, Jak bawić się i uczyć z pasją? Zastosowanie narzędzi myślowych TOC w pracy $z$ dziećmi, Kraków.

Karbowniczek J., 2012, Zintegrowana edukacja wczesnoszkolna z językiem angielskim, Warszawa.

Kotorowicz-Jasińska K., Śpiewak G., 2016, Train your brain. Ideas and activities for remembering easily and revising wisely, Warszawa.

Lipińska E., Seretny A., 2012, Między językiem ojczystym a obcym. Nauczanie i uczenie się języka odziedziczonego na przyktadzie szkolnictwa polonijnego w Chicago, Kraków.

Miodunka W., 2010, Polszczyzna jako język drugi. Definicja języka drugiego, in: J. S. Gruchała, H. Kurek (eds.), Silva Rerum Philologicarum. Studia oferowane profesor Marii Strycharskiej-Brzezinie z okazji Jej jubileuszu, Kraków, pp. 233-246.

Miodunka W., 2016, Glottodydaktyka polonistyczna. Pochodzenie - stan obecny - perspektywy, Kraków.

ORPEG, 2019, Narzędzia TOC wspomagajace procesy edukacyjne w polskiej szkole poza granicami kraju, http://www.orpeg.pl/index.php/aktalnosci-pcn/48-aktualnosci-pcn/1654-narzedzia-toc-wspomagajace-procesy-edukacyjne-w-polskiej-szkole-poza-granicami-kraju [20.04.2019].

Pfeiffer W., 2001, Nauka języków obcych: od praktyki do praktyki, Poznań.

Przewęda R., 1981, Rozwój somatyczny i motoryczny, Warszawa. 
Rokita-Jaśkow J., 2015, Spór o metodę, czyli jak najlepiej uczyć dzieci języków obcych, "Języki Obce w Szkole", no. 1, pp. 31-35.

Schaffer H. R., 2006, Psychologia dziecka, Warszawa.

Sobczyńska D., 2016, Praktyka czyni (prawie) mistrza, czyli jak uczyć po angielsku nie tylko angielskiego, "Języki Obce w Szkole", no. 3, pp. 105-198.

Szewczuk W., 2000, Podstawy psychologii. Podręcznik akademicki, Warszawa.

Szybura A., 2016, Potrzeby językowe uczniów przybywających z zagranicy w zakresie nauczania języka polskiego, "Języki Obce w Szkole", no. 2, pp. 99-105.

Żydek-Bednarczuk U., 2015, Spotkanie kultur: komunikacja i edukacja międzykulturowa w glottodydaktyce, Katowice.

\section{Magdalena Smoleń-Wawrzusiszyn}

\section{GALĄZKA LOGICZNA TOC W NAUCZANIU JEZZYKA POLSKIEGO JAKO OBCEGO/DRUGIEGO/ODZIEDZICZONEGO DZIECI}

Słowa kluczowe: narzędzia myślowe TOC, gałązka logiczna, glottodydaktyka polonistyczna, nauczanie języka polskiego jako obcego/drugiego/odziedziczonego dzieci

Streszczenie. Artykuł jest poświęcony prezentacji autorskich rozwiązań w zakresie adaptacji jednego z narzędzi myślowych TOC dla potrzeb glottodydaktyki polonistycznej, a konkretnie - w nauczaniu języka polskiego jako obcego, drugiego bądź odziedziczonego dzieci. Narzędzia myślowe TOC zostały prymarnie wypracowane dla sfery biznesu jako narzędzia do diagnozowania obszarów wymagających poprawy lub usprawnienia. Przeniesione do sfery edukacji okazały się uniwersalnymi metodami wspierania procesów poznawczych uczniów. W dotychczasowych badaniach nad możliwymi zastosowaniami metodologii TOC nie zwracano uwagi na jej wykorzystanie w działaniach glottodydaktycznych, a tymczasem narzędzia TOC wydają się przydatnym rozwiązaniem w nauczaniu języków obcych dzieci. W artykule przedstawione są propozycje wykorzystania tzw. gałązki logicznej do objaśniania reguł gramatycznych w nauczaniu języka polskiego dzieci. Omawiane narzędzie dydaktyczne może dobrze spełniać tę funkcję, ponieważ odpowiada standardom metodyki odpowiedniej w kształceniu językowym dzieci: jest atrakcyjne jako narzędzie graficzne, pokazuje struktury systemu polszczyzny w sposób przejrzysty i uporządkowany, ma walory mnemotechniczne, może być wykorzystane do gier i zabaw glottodydaktycznych, jak również pozwala na elastyczność (różnicowanie) procesu dydaktycznego. 